\title{
Synthesis of dehydrodipeptide and $N$-ethyl-dehydrodipeptide derivatives with an $\alpha$-aminoisobutyric acid residue
}

Running Title: Synthesis of $\boldsymbol{N}$-ethyl-dehydrodipeptides

Luís S. Monteiro ${ }^{\mathrm{a}^{*} \text {, Silvia M. M. A. Pereira-Lima }{ }^{\mathrm{a}} \text { and Sofia Pereira }}{ }^{\mathrm{a}}$

${ }^{a}$ Chemistry Centre, University of Minho, Gualtar, 4710-057 Braga, Portugal

Corresponding author's address: L. S. Monteiro, Chemistry Centre, University of Minho, Gualtar, $4710-057$ Braga, Portugal,

Fax: +351253604382, e-mail: monteiro@quimica.uminho.pt. 


\section{ABSTRACT:}

Several dipeptides with a $N$-benzyloxycarbonyl or a $N$-(tert-butyloxycarbonyl) $\alpha$ aminoisobutyric acid residue and a $\beta$-hydroxyamino acid methyl ester were subject to dehydration to form dehydrodipeptide derivatives. $N$-Ethylation of these dipeptides using triethyloxonium tetrafluoroborate with potassium tert-butoxide as auxiliary base led to complex mixtures that failed to render pure products. However, when the 4-nitrophenylsulfonyl protecting group was substituted for the benzyloxycarbonyl or tert-butyloxycarbonyl groups and $N, N$-diisopropylethylamine was substituted for potassium tert-butoxide, the dehydrodipeptide derivatives were selectively $\mathrm{N}$-alkylated at the amino terminal nitrogen in fair to high yields. Alternatively, $N$-ethylation can be carried out prior to dehydration.

Thus, by a combination of dehydration and $N$-ethylation procedures it was possible to obtain dipeptides with $\alpha$-aminoisobutyric acid and dehydroamino acid residues, which are $N$-alkylated at the amino terminal nitrogen.

\section{KEYWORDS:}

$N$-Alkylamino acids

Alkylation

$N$-Alkyl-dehydrodipeptides

Dehydration

Dehydroamino acids

Dehydrodipeptides

$\alpha, \alpha$-Dialkylglicines 


\section{INTRODUCTION}

Non-proteinogenic amino acids are a valuable class of organic compounds since they can have biological activity per se or can be found in peptides with antibiotic, antiviral, antitumor, anti-inflammatory or immunosuppressive activities.[1-3] In addition, non-proteinogenic amino acids are valuable scaffolds for the assembly of new peptide analogues and mimetics with improved metabolic resistance and bioactivity or with enhanced photophysical properties. Among non-proteinogenic amino acids are $N$-alkylamino acids, dehydroamino acids and $\alpha, \alpha$ dialkylamino acids, all of which can be found in many biologically important peptides.[1-3]

$N$-Alkylamino acids are present in naturally occurring peptides and proteins. [1-3] The alkyl group attached to the amine function causes changes in volume and conformation of peptides; those changes result in reduced flexibility, increased lipophilicity and prevention of degradation by proteolytic enzymes.[4] Many methods of synthesis of $N$ alkylamino acids have been developed, most of them are $N$-methylations.[4] Belsito et al. proposed the ethylation of several 4-nitrophenylsulfonyl (Nosyl) protected amino acids using triethyloxonium tetrafluoroborate $\left(\mathrm{Et}_{3} \mathrm{OBF}_{4}\right)$ as alkylating agent and $N, N$-diisopropylethylamine (DIPEA) as base to form $N$-ethylamino acid derivatives in high yields.[5] Subsequently, these authors proposed the use of trimethyloxonium tetrafluoroborate $\left(\mathrm{Me}_{3} \mathrm{OBF}_{4}\right)$ to obtain the corresponding $N$-methylated amino acid derivatives.[6]

A combination of the alkylation procedure described above and dehydration methodologies $[7,8]$ developed in our group, gave new non-proteinogenic amino acids namely, $N$-(4-nitrophenylsulfonyl), $N$-ethyl- $\alpha, \beta$-dehydroamino acids. [9] The application of this $N$-alkylation procedure to several methyl esters of $\beta, \beta$-dibromo and $\beta$-bromo, $\beta$ substituted dehydroamino acids protected with standard amine protecting groups was subsequently reported.[10] By substituting potassium tert-butoxide for $N, N$-diisopropylethylamine the method was applied to obtain in high yields $N$-ethyl $\beta$-halogenated dehydroamino acid derivatives and also non-halogenated $N$-ethyl dehydroamino acid derivatives. [11]

$\alpha, \alpha$-Dialkylglycines, such as $\alpha$-aminoisobutyric acid (Aib), also known as dimethylglycine or 2-methylalanine, diethylglycine (Deg) and isovaline (Iva) are the main feature of peptaibols. Peptaibols are a family of naturally occurring antibiotic peptides isolated from soil fungi which exhibit a broad range of activities against Gram-negative and Gram-positive bacteria and fungi.[12] Owing to their non-proteinogenic nature, the introduction of these amino acids in peptides results in increased resistance to proteolytic enzymes and more defined conformations. [13-14] 
Recently, we explored $N$-ethylation and $N$-methylation of several $N$-protected derivatives of $\alpha$-aminoisobutyric acid using the corresponding trialkyloxonium tetrafluoroborate with potassium tert-butoxide as auxiliary base.[15] $N$ Alkylated $\alpha$-aminoisobutyric acid derivatives were obtained in good to high yields.

Herein, we explore the combination of dehydration and $N$-alkylation procedures to form dipeptides combining dehydroamino acid and $\alpha$-aminoisobutyric acid residues as well as dipeptides with both dehydroamino acid and $\alpha$ aminoisobutyric acid residues and additionally $N$-alkylated in one residue.

\section{MATERIALS AND METHODS}

Representative procedure for the synthesis of the methyl esters of $N$-benzyloxycarbonyl or $N$-(tertbutyloxycarbonyl)-dehydrodipeptides (compounds 2a-d).

To a solution of Z-Aib-D,L-Phe $(\beta-\mathrm{OH})-\mathrm{OMe}(\mathbf{1 c})(0.414 \mathrm{~g}, 1.000 \mathrm{mmol})$ in dry acetonitrile $\left(0.2 \mathrm{~mol} \mathrm{dm}{ }^{-3}\right), 0.1$ equiv. of dimethylaminopyridine was added, followed by 1.0 equiv of tert-butylpyrocarbonate, under rapid stirring at room temperature. The reaction was monitored by TLC (diethyl ether/ $n$-hexane, 1:1) until all the reactant had been consumed. Then $2 \%$ in volume of $N, N, N^{\prime}, N^{\prime}$-tetramethylguanidine was added, stirring was continued for 16 hours. When all the reactant was consumed evaporation at reduced pressure gave a residue that was partitioned between $100 \mathrm{~mL}$ of diethyl ether and $30 \mathrm{~mL}$ of $\mathrm{KHSO}_{4}\left(1 \mathrm{~mol} \mathrm{dm}^{-3}\right)$. The organic phase was thoroughly washed with $\mathrm{KHSO}_{4}\left(1 \mathrm{~mol} \mathrm{dm}^{-3}\right), \mathrm{NaHCO}_{3}\left(1 \mathrm{~mol} \mathrm{dm}^{-3}\right)$ and saturated brine $(2$ x $30 \mathrm{~mL}$ each $)$. The organic layer was dried with $\mathrm{MgSO}_{4}$ and the solvent evaporated at reduced pressure. Removal of the solvent afforded $\mathbf{2 c}(0.305 \mathrm{~g}, 77 \%)$ as a white solid. (from ethyl acetate/n-hexane). M.p. 106.0-107.0 ${ }^{\circ}$ C. ${ }^{1} \mathrm{H}$ NMR $\left(300 \mathrm{MHz}, \mathrm{CDCl}_{3}\right): \delta=1.60[\mathrm{~s}, 6 \mathrm{H}$, $\left.\mathrm{C}\left(\mathrm{CH}_{3}\right)_{2}\right], 3.83\left(\mathrm{~s}, 3 \mathrm{H}, \mathrm{OCH}_{3}\right), 5.12\left(\mathrm{~s}, 2 \mathrm{H}, \mathrm{CH}_{2} \mathrm{Z}\right), 5.33$ (s, 1H, NH), 7.32-7.40 (m, 10H, ArH), 7.52 (s, 1H, $\left.\beta \mathrm{CH}\right)$, $8.03(\mathrm{~s}, 1 \mathrm{H}, \mathrm{NH})$ ppm. ${ }^{13} \mathrm{C} \mathrm{NMR}\left(75.4 \mathrm{MHz}, \mathrm{CDCl}_{3}\right): \delta=25.16\left[\mathrm{C}^{\left.\left(\mathrm{CH}_{3}\right)_{2}\right],} 52.58\left(\mathrm{OCH}_{3}\right), 57.37\left[C\left(\mathrm{CH}_{3}\right)_{2}\right], 66.95\right.$ $\left(\mathrm{CH}_{2}\right), 124.12(\alpha \mathrm{C}) 128.08(\mathrm{CH}), 128.24(\mathrm{CH}), 128.43(\mathrm{CH}), 128.54(\mathrm{CH}), 129.37(\mathrm{CH}), 129.82(\mathrm{CH}), 132.18(\mathrm{CH})$, 133.64 (C), 135.89 (C), $155.15(\mathrm{C}=\mathrm{O}), 165.60(\mathrm{C}=\mathrm{O}), 172.73(\mathrm{C}=\mathrm{O})$ ppm. $\mathrm{C}_{22} \mathrm{H}_{24} \mathrm{~N}_{2} \mathrm{O}_{5}$ (396.44): calcd. C 66.65, $\mathrm{H}$ 6.10, N 7.07; found C 66.38, H 6.13, N 7.36.

\footnotetext{
Representative procedure for the synthesis of the methyl esters of $N$-(4-nitrobenzenesulfonyl)dehydrodipeptides (compounds 4a-c)
} 
The procedure described above for the synthesis of $2 \mathrm{c}$ was followed using Nosyl-Aib-L-Thr-OMe (3b) (0.403 g, $1.000 \mathrm{mmol})$ as reactant to afford $4 \mathbf{b}(0.362 \mathrm{~g}, 94 \%)$ as a white solid. M.p. $155.0-156.0^{\circ} \mathrm{C} .{ }^{1} \mathrm{H}$ NMR $(400 \mathrm{MHz}$, $\left.\mathrm{CDCl}_{3}\right): \delta=1.53\left[\mathrm{~s}, 6 \mathrm{H},\left(\mathrm{CH}_{3}\right)_{2}\right], 1.78\left(\mathrm{~d}, J=7.2 \mathrm{~Hz}, 3 \mathrm{H}, \gamma \mathrm{CH}_{3}\right), 3.78\left(\mathrm{~s}, 3 \mathrm{H}, \mathrm{OCH}_{3}\right), 6.18(\mathrm{~s}, 1 \mathrm{H}, \mathrm{NH}), 6.87(\mathrm{q}, J=$ $7.2 \mathrm{~Hz}, 1 \mathrm{H}, \beta \mathrm{CH}), 7.56(\mathrm{~s}, 1 \mathrm{H}, \mathrm{NH}), 8.11(\mathrm{~d}, J=8.8 \mathrm{~Hz}, 2 \mathrm{H}, \mathrm{ArH}), 8.36(\mathrm{~d}, J=8.8 \mathrm{~Hz}, 2 \mathrm{H}, \mathrm{ArH}) \mathrm{ppm} .{ }^{13} \mathrm{C}$ NMR $\left(100.6 \mathrm{MHz}, \mathrm{CDCl}_{3}\right): \delta=14.51\left(\gamma \mathrm{CH}_{3}\right), 26.03\left[\mathrm{C}\left(\mathrm{CH}_{3}\right)_{2}\right], 52.47\left(\mathrm{OCH}_{3}\right), 60.36\left[C\left(\mathrm{CH}_{3}\right)_{2}\right], 124.32(\mathrm{CH}), 124.40$ $(\mathrm{CH}), 125.53(\mathrm{C}), 128.23(\mathrm{CH}), 128.97(\mathrm{CH}), 135.40(\mathrm{CH}), 148.15(\mathrm{C}), 149.97(\mathrm{C}), 164.77(\mathrm{C}=\mathrm{O}), 172.03(\mathrm{C}=\mathrm{O})$ ppm. $\mathrm{C}_{15} \mathrm{H}_{19} \mathrm{~N}_{3} \mathrm{O}_{7} \mathrm{~S}$ (385.39): calcd. C 46.75, H 4.97, N 10.90, S 8.32; found C 46.67, H 4.89, N 10.79, S 8.30.

Representative procedure for the synthesis of the methyl esters of $\mathrm{N}$-(4-nitrobenzenesulfonyl), $\mathrm{N}$ ethyldehydrodipeptides (compounds 5a-c) by $N$-ethylation of the methyl esters of $N$-(4-nitrobenzenesulfonyl) dehydrodipeptides (compounds 4a-c).

To a solution of Nosyl-Aib-L- $\triangle$ Abu-OMe $(4 \mathbf{b})(0.154 \mathrm{~g}, 0.400 \mathrm{mmol})$ in dry dichloromethane $\left(0.2 \mathrm{~mol} \mathrm{dm}^{-3}\right)$ followed by addition of 3.5 eq. of potassium tert-butoxide and 2.2 eq. of trialkyloxonium tetrafluoroborate under inert atmosphere. The reaction mixture was stirred at room temperature for $30 \mathrm{~min}$. Then dichloromethane $\left(50 \mathrm{~cm}^{3}\right)$ was added. The organic phase was washed with $\mathrm{KHSO}_{4}\left(1 \mathrm{~mol} \mathrm{dm}^{-3}\right), \mathrm{NaHCO}_{3}\left(1 \mathrm{~mol} \mathrm{dm}^{-3}\right)$ and brine $\left(2 \times 20 \mathrm{~cm}^{3}\right.$ each), dried over $\mathrm{MgSO}_{4}$ and evaporated at reduced pressure. Removal of the solvent afforded $\mathbf{5 b}(0.114 \mathrm{~g}, 69 \%)$ as a light yellow solid. M.p. $154.0-155.0{ }^{\circ} \mathrm{C}$. (from ethyl acetate/ $n$-hexane). ${ }^{1} \mathrm{H}$ NMR (400 $\mathrm{MHz}, \mathrm{CDCl}_{3}$ ): (rotamers) $\delta$ $=1.31\left(\mathrm{t}, J=7.2 \mathrm{~Hz}, 3 \mathrm{H}, \mathrm{CH}_{2} \mathrm{CH}_{3}\right), 1.64\left[\mathrm{~s}, 6 \mathrm{H},\left(\mathrm{CH}_{3}\right)_{2}\right], 1.69\left(\mathrm{~d}, J=7.2 \mathrm{~Hz}, 3 \mathrm{H}, \gamma \mathrm{CH}_{3}\right), 3.64-3.66\left(\mathrm{~m}, 5 \mathrm{H}, \mathrm{CH}_{2} \mathrm{CH}_{3}\right.$ $\left.+\mathrm{OCH}_{3}\right), 6.79(\mathrm{q}, J=7.2 \mathrm{~Hz}, 1 \mathrm{H}, \beta \mathrm{CH}), 6.93(\mathrm{~d}, J=9.6 \mathrm{~Hz}, 2 \mathrm{H}, \mathrm{ArH}), 7.77$ (br. s, $\left.1 \mathrm{H}, \mathrm{NH}\right), 8.12(\mathrm{~d}, J=9.6 \mathrm{~Hz}$, $2 \mathrm{H}, \mathrm{ArH})$ ppm. ${ }^{13} \mathrm{C} \mathrm{NMR}\left(100.6 \mathrm{MHz}, \mathrm{CDCl}_{3}\right)$ : (rotamers) $\delta=14.48\left(\gamma \mathrm{CH}_{3}\right), 14.58\left(\mathrm{CH}_{2} \mathrm{CH}_{3}\right), 24.56,25.83$ [C( $\left.\left(\mathrm{CH}_{3}\right)_{2}\right], 41.88\left(\mathrm{CH}_{2} \mathrm{CH}_{3}\right), 52.23\left(\mathrm{OCH}_{3}\right), 64.81\left[\mathrm{C}\left(\mathrm{CH}_{3}\right)_{2}\right], 117.22(\mathrm{CH}), 125.07(\mathrm{CH}), 125.76(\mathrm{CH}), 134.17(\mathrm{C})$, 139.90 (C), 151.57 (C), $164.60(\mathrm{C}=\mathrm{O}), 173.95(\mathrm{C}=\mathrm{O})$ ppm. HRMS (ESI): calcd. for $\mathrm{C}_{17} \mathrm{H}_{24} \mathrm{~N}_{3} \mathrm{O}_{7} \mathrm{~S} 414.13350$; found 414.13317.

Representative procedure for the synthesis of the methyl esters of $N$-(4-nitrobenzenesulfonyl), $N$ ethyldipeptides (compounds 6a-c). 
The procedure described above for the synthesis of compound $\mathbf{5 b}$ was followed using Nosyl-Aib-L-Thr-OMe (3b) $(0.403 \mathrm{~g}, 1.000 \mathrm{mmol})$ as reactant to afford $6 \mathbf{b}(0.405 \mathrm{~g}, 94 \%)$ as a light yellow solid. M.p. $95.0-96.0^{\circ} \mathrm{C}$. (from ethyl acetate/n-hexane). ${ }^{1} \mathrm{H}$ NMR $\left(400 \mathrm{MHz} \mathrm{CDCl}_{3}\right)$ : (rotamers) $\delta=1.23-1.33\left(\mathrm{~m}, 6 \mathrm{H}, \mathrm{CH}_{2} \mathrm{CH}_{3}+\gamma \mathrm{CH}_{3}\right), 1.60-1.63[2 \mathrm{~s}$, $\left.6 \mathrm{H}, \mathrm{C}\left(\mathrm{CH}_{3}\right)_{2}\right], 3.41-3.46\left(\mathrm{~m}, 2 \mathrm{H}, \mathrm{CH}_{2} \mathrm{CH}_{3}\right], 3.77\left(\mathrm{~s}, 3 \mathrm{H}, \mathrm{OCH}_{3}\right), 4.36-4,41(\mathrm{~m}, 1 \mathrm{H}, \beta \mathrm{CH}), 4.54(\mathrm{dd}, J=2.8 \mathrm{~Hz}, J=$ $8.6 \mathrm{~Hz}, 1 \mathrm{H}, \alpha \mathrm{CH}), 7.00(\mathrm{~d}, J=8.4 \mathrm{~Hz}, 1 \mathrm{H}, \mathrm{NH}), 8.17(\mathrm{~d}, 2 \mathrm{H}, J=8.8 \mathrm{~Hz}, \mathrm{ArH}), 8.34(\mathrm{~d}, 2 \mathrm{H}, J=8.8 \mathrm{~Hz}, \mathrm{ArH}) \mathrm{ppm}$. ${ }^{13} \mathrm{C}$ NMR $\left(100.6 \mathrm{MHz}, \mathrm{CDCl}_{3}\right)$ : (rotamers) $\left.\delta=16.48\left(\mathrm{CH}_{2} \mathrm{CH}_{3}\right), 20.11\left(\gamma \mathrm{CH}_{3}\right), 25.96,26.09\left[\mathrm{C}\left(C \mathrm{H}_{3}\right)_{2}\right)\right], 41.76$ $\left(\mathrm{CH}_{2} \mathrm{CH}_{3}\right), 52.56\left(\mathrm{OCH}_{3}\right), 57.71(\alpha \mathrm{CH}), 65.49\left[\mathrm{C}\left(\mathrm{CH}_{3}\right)_{2}\right], 68.15(\beta \mathrm{CH}), 124.23(\mathrm{CH}), 129.01(\mathrm{CH}), 147.10(\mathrm{C})$, $149.95(\mathrm{C}), 171.22(\mathrm{C}=\mathrm{O}), 174.45(\mathrm{C}=\mathrm{O}) \mathrm{ppm}$.

Representative procedure for the synthesis of the methyl esters of $N$-(4-nitrobenzenesulfonyl), $N$ ethyldehydrodipeptides (compounds 5a-c) by dehydration of the methyl esters of $N$-(4-nitrobenzenesulfonyl), $N$-ethyldipeptides (compounds 6a-c).

The procedure described above for the synthesis of compounds $\mathbf{2 c}$ and $\mathbf{4 b}$ was followed using Nosyl-N(Et)Aib-LThr-OMe (6b) (0.172 g, $0.400 \mathbf{m m o l})$ as reactant to afford $\mathbf{5 b}(0.235 \mathrm{~g}, 61 \%)$.

\section{RESULTS AND DISCUSSION}

Several dipeptides were prepared by coupling $N$-benzyloxycarbonyl or $N$-(tert-butyloxycarbonyl) $\alpha$-aminoisobutyric acid with the methyl esters of the $\beta$-hydroxyamino acids serine, threonine and phenylserine, using the conventional DCC/HOBt procedure (Scheme 1, compounds 1a-d). These were subject to dehydration by reaction with 1 equivalent of tert-butyl pyrocarbonate in the presence of dimethylaminopyridine (DMAP) as catalyst, followed by treatment with $N, N, N^{\prime}, N^{\prime}$-tetramethylguanidine (TMG). Thus, dipeptides containing an $\alpha$-aminoisobutyric acid and a dehydroamino acid residue were prepared in moderate to good yields (Scheme 1, yields of 46\%, 62\%, 77\% and $74 \%$ for compounds $\mathbf{2 a}, \mathbf{2 b}, \mathbf{2} \mathbf{c}$ and $\mathbf{2 d}$, respectively).

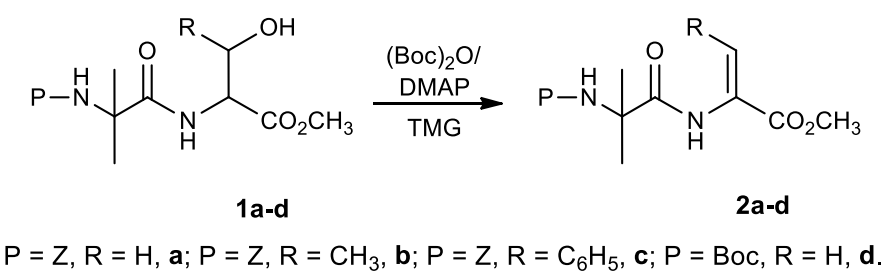


Scheme 1. Synthesis of the methyl esters of $N$-benzyloxycarbonyl or $N$-(tert-butyloxycarbonyl)-dehydrodipeptides (compounds 2a-d).

Dipeptides 2a-d were subject to tentative $N$-ethylation using triethyloxonium tetrafluoroborate with potassium tertbutoxide as auxiliary base. However, a complex mixture resulting from mono and diethylation was obtained and did not allow isolation of any pure product.

In order to circumvent these difficulties, the substitution of the benzyloxycarbonyl or the tert-butyloxycarbonyl groups for the 4-nitrophenylsulfonyl group was proposed. The use of this more electron-withdrawing protecting group, in combination with the weaker auxiliary base $N, N$-diisopropylethylamine, would allow ethylation to occur only on the amino terminal nitrogen. Thus, dipeptides were prepared by coupling $N$-(4-nitrobenzenesulfonyl)- $\alpha$ aminoisobutyric acid with the methyl esters of serine, threonine and phenylserine (Scheme 2, compounds 3a-c). These were subject to dehydration by the procedure described previously to form the methyl esters of $N$-(4nitrobenzenesulfonyl) dehydrodipeptides (Scheme 2, yields of $82 \%, 94 \%$ and $64 \%$ for compounds $\mathbf{4 a}, \mathbf{4 b}$ and $\mathbf{4 c}$, respectively).

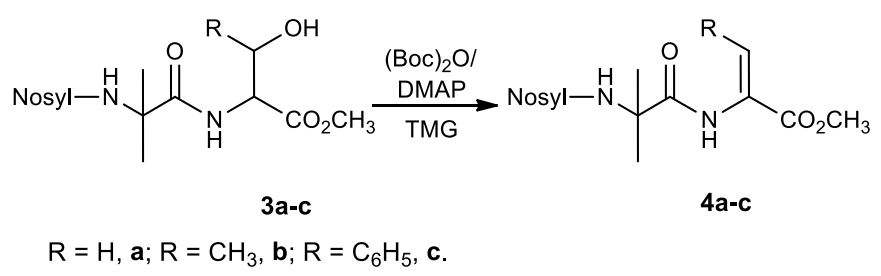

Scheme 2. Synthesis of the methyl esters of $N$-(4-nitrobenzenesulfonyl)-dehydrodipeptides (compounds 4a-c).

Dipeptides 4a-c were subject to $N$-ethylation using triethyloxonium tetrafluoroborate with $N, N$ diisopropylethylamine as auxiliary base. The corresponding methyl esters of $N$-(4-nitrobenzenesulfonyl), $N$-ethyl dehydrodipeptides were formed in good yields (Scheme 3, yields of 71\%, 69\% and $86 \%$ for compounds $\mathbf{5 a}, \mathbf{5 b}$ and 5c, respectively). 


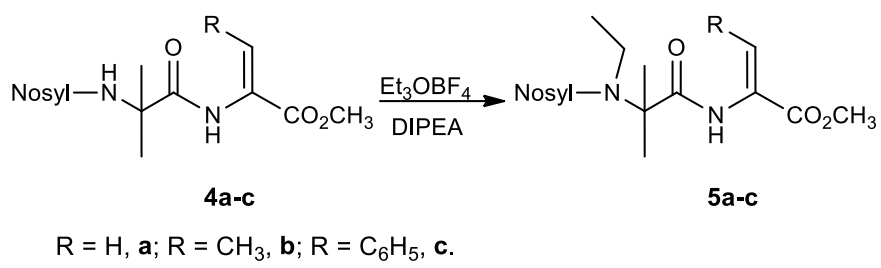

Scheme 3. Synthesis of the methyl esters of $N$-(4-nitrobenzenesulfonyl), $N$-ethyldehydrodipeptides (compounds 5a-

c) by $N$-ethylation of the methyl esters of $N$-(4-nitrobenzenesulfonyl) dehydrodipeptides (compounds 4a-c).

Alternatively, $N$-ethylation can be carried out prior to dehydration giving $N$-(4-nitrobenzenesulfonyl), $N$-ethyl, dipeptide derivatives in high yields (Scheme 4, yields of $81 \%$, 94\% and $87 \%$ for compounds $6 \mathbf{a}$, 6b and $\mathbf{6 c}$, respectively).

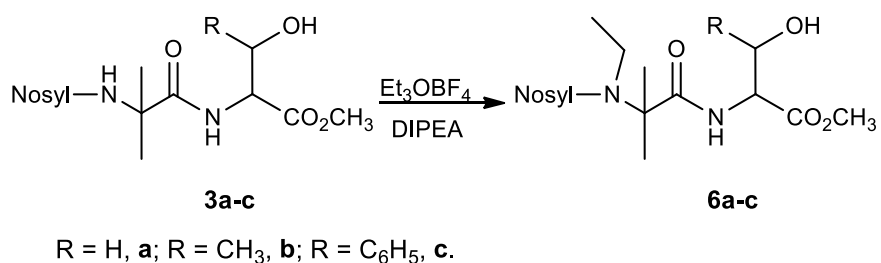

Scheme 4. Synthesis of the methyl esters of $N$-(4-nitrobenzenesulfonyl), $N$-ethyldipeptides (compounds 6a-c).

These can now be dehydrated to form the corresponding $N$-(4-nitrobenzenesulfonyl), $N$-ethyldehydrodipeptide derivatives (Scheme 5, yields of $88 \%, 61 \%$ and $88 \%$ for compounds $\mathbf{5 a}, \mathbf{5 b}$ and $\mathbf{5 c}$, respectively).

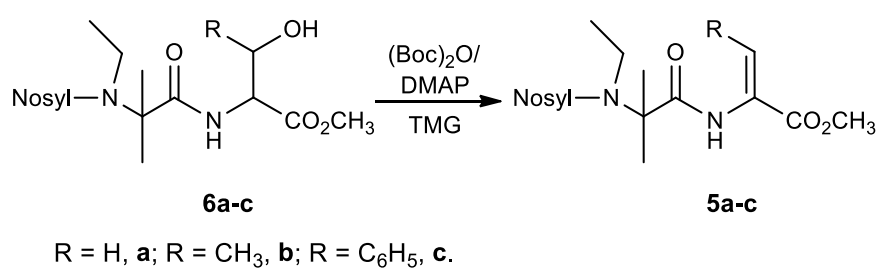

Scheme 5. Synthesis of the methyl esters of $N$-(4-nitrobenzenesulfonyl), $N$-ethyldehydrodipeptides (compounds 5ac) by dehydration of the methyl esters of $N$-(4-nitrobenzenesulfonyl), $N$-ethyldipeptides (compounds 6a-c). 
Both routes allow the preparation of $N$-ethyl $\alpha$-aminoisobutyric acid containing dehydrodipeptide derivatives in moderate to good yields. The route involving dehydration followed by $\mathrm{N}$-ethylation gives overall yields of $58 \%$, $65 \%$ and $55 \%$ for the dehydroalanine, dehydroaminobutyric acid and dehydrophenylalanine dipeptide derivatives, respectively. The pathway of $N$-ethylation followed by dehydration gives yields of $71 \%, 57 \%$ and $77 \%$, respectively. Thus, the latter route seems to be favorable for the preparation of $N$-ethyl $\alpha$-aminoisobutyric acid containing dehydrodipeptides with dehydroalanine and dehydrophenylalanine residues, whilst both routes give comparable yields for the dehydrodipeptide derivative with the dehydroaminobutyric acid residue.

\section{CONCLUSION}

By a combination of dehydration and $N$-ethylation procedures it was possible to obtain dehydrodipeptides with $\alpha$ aminoisobutyric acid and dehydroamino acid residues that could additionally be $N$-alkylated at the amino terminal nitrogen. Thus, it was possible to obtain for the first time peptides containing simultaneously $N$-ethyl, $\alpha, \alpha$-dimethyl and dehydro moieties, namely $N$-ethyl $\alpha$-aminoisobutyric acid containing dehydrodipeptide derivatives. These nonproteinogenic dipeptides with more defined conformations, increased resistance to proteolytic enzymes and increased lipophilicity, can be important for biological and pharmacological applications. The peptides derivatives obtained can be applied, among others targets, for the preparation of peptaibol derivatives with potential biomedical applications or of new small peptide hydrogelators. 


\section{ACKNOWLEDGMENTS}

Foundation for Science and Technology (FCT) - Portugal and Fundo Europeu de Desenvolvimento Regional (FEDER) for financial support to Chemistry Centre of University of Minho. The NMR spectrometer Bruker Avance $\mathrm{II}^{+} 400$ is part of the National NMR Network and was purchased in the framework of the National Program for Scientific Re-equipment; contract REDE/1517/RMN/2005, with funds from POCI 2010, FEDER and FCT.

\section{REFERENCES}

[1] Gilon C, Dechantsreiter MA, Burkhart F, Friedler A, Kessler H. Synthesis of $N$-alkylated peptides. In: Goodman M, Felix A, Moroder L, Toniolo C., Eds. Methods of organic chemistry. Synthesis of peptides and peptidomimetics. New York, NY: Thieme Verlag, 2002: Pp. 215-271.

[2] Kotha S. The building block approach to unusual $\alpha$-amino acid derivatives and peptides. Acc Chem Res 2003; 36: $342-351$.

[3] Rilatt I, Caggiano L, Jackson RFW. Development and applications of amino acid derived organometallics. Synlett 2005; 2701-2719.

[4] Aurelio L, Brownlee RTC, Hughes AB. Synthetic preparation of $N$-methyl-alpha-amino acids. Chem Rev 2004; 104: 5823-5846.

[5] Belsito EL, De Marco R, Di Gioia ML, Liguori A, Perri F, Viscomi MC. N-(4-Nitrophenylsulfonyl)- and N(fluorenylmethoxycarbonyl)- $N$-ethyl amino acid methyl esters - A practical approach. Eur J Org Chem 2010; 42454252.

[6] De Marco R, Di Gioia ML, Liguori A, Perri F, Siciliano C, Spinella M. $N$-Alkylation of $N$-arylsulfonyl-alphaamino acid methyl esters by trialkyloxonium tetrafluoroborates. Tetrahedron 2011; 67: 9708-9714.

[7] Ferreira PMT, Maia HLS, Monteiro LS, Sacramento J. High yielding synthesis of dehydroamino acid and dehydropeptide derivatives. J Chem Soc, Perkin Trans 1 1999; 3697-3703.

[8] Ferreira PMT, Monteiro LS, Pereira G, Ribeiro L, Sacramento J, Silva L. Reactivity of dehydroamino acids and dehydrodipeptides towards $N$-bromosuccinimide: Synthesis of beta-bromo- and beta,beta-dibromodehydroamino acid derivatives and of substituted 4-imidazolidinones. Eur J Org Chem 2007; 5934-5949. 
[9] Monteiro LS, Kołomańska J, Suárez AC. Synthesis of novel nonproteinogenic amino acids: $N$-Ethyl-alpha,betadehydroamino acid methyl esters. Eur J Org Chem 2010; 6731-6735.

[10] Monteiro LS, Andrade JJ, Suárez AC. Synthesis of new $N$-ethyl dehydroamino acid derivatives: $N$-Ethyl beta,beta-dibromo, $N$-ethyl beta-bromo beta-substituted, and $N$-ethyl beta,beta-disubstituted $N$-protected dehydroamino acid methyl esters. Eur J Org Chem 2011; 6764-6772.

[11] Monteiro LS, Suárez AC. High yielding synthesis of $N$-ethyl dehydroamino acids. Amino Acids 2012; 43: $1643-1652$.

[12] Duclohier H. Peptaibiotics and peptaibols: An alternative to classical antibiotics? Chem Biodivers 2007; 4: $1023-1026$.

[13] Aravinda S, Shamala N, Balaram P. Aib Residues in peptaibiotics and synthetic sequences: Analysis of nonhelical conformations. Chem Biodivers 2008; 5: 1238-1262.

[14] Maekawa H, Ballano G, Toniolo C, Ge N-H. Linear and two-dimensional infrared spectroscopic study of the amide I and II modes in fully extended peptide chains. J Phys Chem B 2011; 115: 5168-5182.

[15] Monteiro LS, Pereira-Lima SMMA, Pereira S, Machado JN. Synthesis of $N$-alkyl- $C$-alpha,alphadimethylglycine derivatives. Arkivoc 2014; (v): 170-180. 